\title{
EVALUASI PROGRAM DESAIN PEMBELAJARAN PENDIDIKAN AGAMA ISLAM MELALUI MODEL CONTEXT, INPUT, PROCESS, PRODUCT (CIPP)
}

\author{
Nur Amalina \\ IAIN Palopo \\ E-mail: nuramalinampd@gmail.com
}

\begin{abstract}
Abstrak
Penelitian ini bertujuan untuk mengetahui aspek context, input, process dan product desain pembelajaran PAI di SMA Negeri 4 Palopo. Penelitian ini adalah penelitian kualitatif yang menggunakan pendekatan manajemen. Analisis data yang digunakan adalah deskriptif analisis dengan melakukan reduksi data, penyajian data, dan penarikan kesimpulan.

Hasil penelitian ini menunjukkan bahwa: (1) Ditinjau dari aspek context, bentuk desain pembelajaran PAI yang digunakan adalah desain pembelajaran PAI berbasis kurikulum 2013 yang dirumuskan secara individu dan kelompok. Adapun kualifikasi guru sudah sesuai dengan latar belakang pendidikannya namun kompetensi pedagogik sebagian guru masih kurang maksimal dan faktor penunjang yaitu komputer, kertas dan printer. (2) Ditinjau dari aspek input, dukungan sekolah dan usaha guru masih kurang maksimal. (3) Ditinjau dari aspek process, pemamfaatan desain pembelajaran PAI terkadang sesuai dan terkadang juga tidak sesuai. Waktu pembuatan desain PAI dilakukan setiap awal semester walaupun terkadang perangkat pembelajaran belum selesai semuanya padahal masa pemamfaatan desain pembelajaran PAI berlaku untuk satu semester. (4) Ditinjau dari aspek product, pemamfaatan desain pembelajaran PAI menimbulkan dampak positif dan dampak negatif dan respon siswa menimbulkan respon positif dan respon negatif.
\end{abstract}

Kata Kunci,: Evaluasi Program, Desain Pembelajaran PAI, Model CIPP

\begin{abstract}
This study aims to determine aspects of context, input, process and product Islamic Instructional Design in SMAN 4 Palopo. This study is a qualitative research. The approach was management. Analysis of the data used were descriptive analysis by performing data reduction, data presentation, and conclusion.

The results of this study indicate that: (1) According to context, form of Islamic instructional design used was a curriculum-based learning design in 2013 formulated individually. The teachers' qualifications were accordance with the educational background and pedagogical competence of some teachers was still less than the maximum, and supporting factors were computer, papers, and printer. (2) According to input, the support of school and effort of the teachers was still less than the maximum. (3) According to process, the suitability of the utilization of the Islamic instructional design was sometimes appropriate and sometimes not appropriate. The time of making the Islamic instructional design conducted beginning of each semester, although sometimes the Islamic instructional design has not finished and the period of utilization of the Islamic instructional design was for one semester. (4) According to product, the impact of the utilization of the Islamic instructional design have positive impacts and negative impacts, and the students' responses to the utilization of the Islamic instructional design have positive response and negative response.
\end{abstract}

Keywords: Evaluation Program, Islamic Instructional Design , CIPP Model 


\section{8 | Nur Amalina}

\section{Pendahuluan}

Pendidikan pada dasarnya merupakan interaksi antara pendidik dengan peserta didik. Seiring dengan berkembangnya pendidikan dan sistem pendidikan di Indonesia, maka seluruh elemen masyarakat utamanya yang terkait langsung dengan kegiatan pendidikan dituntut untuk lebih kreatif dan profesional untuk mengembangkan pendidikan. Selain itu, para pelaku pendidikan juga diharapkan dalam melaksanakan pendidikan sesuai dengan prosedur yang telah diterapkan bersama sesuai dengan kebutuhan dan tantangan pendidikan.

Untuk itulah perlu adanya perencanaan pembelajaran yang matang untuk menghadapi tantangan-tantangan yang muncul seiring dengan berkembangnya waktu. Perencanaan pembelajaran tersebut perlu dilakukan agar guru dapat mengkoordinasikan berbagai komponen pembelajaran yang berorientasi pada pembentukan kompetensi siswa, yakni kompetensi dasar, meteri standar, indikator hasil belajar, dan penilaian berbasis kelas (PBK). Jadi perencanaan pembelajaran yang dimaksud tersebut adalah membuat desain pembelajaran yang diharapkan akan lebih memudahkan proses belajar mengajar, dan khususnya yang berkaitan dengan PAI.

Membuat desain pembelajaran merupakan tahap awal yang harus dilaksanakan untuk melaksanakan proses pembelajaran karena keberhasilan pelaksanaan pembelajaran sangat bergantung pada sejauh mana pembelajaran itu didesain atau direncanakan, sebaliknya pembelajaran yang tidak didesain secara sistematis tidak akan mendapatkan hasil pembelajaran yang maksimal. Desain pembelajaran membantu guru untuk melaksanakan tugasnya sebagai pengajar. Desain yang disusun oleh guru merupakan indikator yang menunjukkan bahwa guru tersebut telah menguasai bahan pelajaran yang akan diberikan kepada peserta didik. Desain pembelajaran yang baik, akan menjadikan pembelajaran lebih berkualitas dan bermakna bagi peserta didik. ${ }^{1}$ Dengan demikian, desain pembelajaran menempati posisi yang teramat penting untuk menunjang dan menjamin kualitas proses dan hasil pembelajaran. Guru diharapkan dalam mendesain pembelajaran PAI dilaksanakan dengan baik dan tentunya sesuai dengan prosedur. Desain pembelajaran yang disusun dengan baik akan berdampak pada pembelajaran dan dapat menimalisir kendala-kendala yang mungkin akan terjadi dalam proses pembelajaran.

Realitas yang terjadi di lapangan berdasarkan hasil observasi penulis pada SMA Negeri 4 Palopo sejumlah guru mata pelajaran PAI kurang maksimal dalam membuat desain pembelajaran PAI. Hal ini disebabkan oleh beberapa faktor. Pertama, guru PAI tidak memiliki cukup kesempatan untuk membuat desain pembelajaran PAI karena terganggu pekerjaan sampingan yang dilakukan selain menjalankan tugas sebagai guru PAI. Kedua, Guru PAI menganggap bahwa pembelajaran yang hendak dilakukan dapat dikuasai sehingga merasa tidak perlu membuat desain pembelajaran. Akibatnya pembelajaran yang dilaksanakan cenderung dilaksanakan dengan pemilihan

h.4.

1Muhammad Yaumi, Prinsip - Prinsip Desain Pembelajaran, (Jakarta: Kencana,2013), 
metode yang tidak tepat, pengelolaan waktu yang tidak sesuai, dan bahan ajar yang tidak terstruktur. ${ }^{2}$

Kecenderungan lain sebagai akibat tidak membuat desain pembelajaran PAI pembelajaran berorientasi pada konten dan mengabaikan tujuan pembelajaran di mana penyajian materi pembelajaran diberikan berdasarkan pengetahuan peserta didik, bukan berdasakan pada kebutuhan peserta didik, metode dan strategi pembelajaran monoton dan hanya berlangsung searah karena tidak memaksimalkan berbagai sumber belajar untuk menjangkau masing-masing individu peserta didik dan penilaian hanya berorientasi pada hasil yang terkadang mengabaikan proses.

Desain pembelajaran yang telah digunakan dalam proses belajar mengajar tentunya akan memberikan pengaruh terhadap guru, peserta didik dan proses belajar mengajar. Hasil akhir penggunaan desain pembelajaran dalam proses belajar mengajar akan terus menerus ditingkatkan untuk keperluan proses belajar mengajar selanjutnya. Oleh sebab itu perlu diadakan evaluasi program untuk mengetahui proses penyusunan desain pembelajaran PAI, dampak pemanfaatan desain pembelajaran PAI dan respon siswa terhadap pemanfaatan desain PAI. Kegiatan evaluasi dilakukan menggunakan model context, input, process, product (CIPP), yang dikembangkan oleh Stufflebeam yang terdiri dari empat komponen evaluasi yaitu context, input, process, dan product yang saling berkaitan.

Sejumlah penelitian telah membuktikan efektivitas penggunaan model CIPP dalam mengevaluasi program pendidikan. Fuat Iskandar melakukan penelitian menggunakan metode penelitian kualitatif deskriptif menemukan bahwa pada komponen context yang menunjukkan adanya relevansi dan hubungan yang kuat antara program pendampingan dengan tujuan dari stakeholder yang terlibat yaitu pihak Direktorat pembinaan SMK, Perguruan tinggi pelaksana dan sekolah kejuruan, pada komponen input institusi pelaksana merupakan perguruan tinggi yang memiliki program studi yang dibutuhkan di sekolah kejuruan dan mampu menyediakan peserta dengan program studi yang sesuai dengan program keahlian di sekolah kejuruan yang menjadi sasaran, pada komponen process, menunjukkan adanya living cost peserta yang kurang mencukupi serta waktu pelaksanaan kurang optimal dikarenakan kurang sesuai dengan tahun ajaran sekolah, dan dari komponen product menunjukkan bahwa semua peserta telah memberikan manfaat bagi sekolah dalam pelaksanaan program pembelajaran di sekolah baik aspek teaching maupun non teaching. ${ }^{3}$ Deby Arisma melakukan penelitian dengan menggunakan metode penelitian kualitatif deskriptif menemukan bahwa evaluasi terhadap context program PSG tergolong tinggi dimana aspek ini terdiri atas kualitas kompetensi yang dimiliki oleh siswa, kesesuaian pelaksanaan program PSG dengan kebijakan dan tujuan yang ditetapkan oleh sekolah, dan kesiapan pengelolaan pelaksanaan yang

2 Obeservasi di SMA Negeri 4 Palopo, tanggal 29 Februari 2016.

${ }^{3}$ Fuat Iskandar, Evaluasi Pelaksanaan Program Pendampingan Penyelenggaraan Pendidikan Kejuruan Direktorat Pembinaan SMK Melalui Model CIPP (Studi Kasus di Universitas Sebelas Maret), Tesis, (Jakarta: Prodi Ilmu Administrasi Kekhususan Administrasi dan Kebijakan Pendidikan, Universitas Indonesia, 2012), h.112.

Volume 4, No.2, Oktober 2019 


\section{0 | Nur Amalina}

dilakukan disekolah tergolong tinggi. Evaluasi terhadap input program PSG tergolong tinggi dimana aspek ini terdiri dari upaya peningkatan kompetensi siswa, upaya peningkatan kesiapan pengelolaan program oleh sekolah, dan upaya peningkatan kesiapan kompetensi guru. Evaluasi terhadap process program PSG tergolong tinggi dimana aspek ini meliputi proses pelaksanaan program PSG dan faktor-faktor yang menghambat dan mendukung pelaksanaan PSG. Evaluasi tehadap product program PSG dalam hal kualitas siswa dan manfaat program PSG tergolong tinggi di mana hal ini meliputi, bagi sekolah dapat menciptakan link and match pembelajaran yang ada di sekolah, bagi siswa dapat meningkatkan kompetensi yang dimiliki siswa dan bagi industri dapat membantu menyelesaikan pekerjaan yang ada. ${ }^{4}$

Selain itu penelitian Junita, dengan menggunakan metode penelitian kualitatif deskrtiptif menemukan bahwa evaluasi terhadap context, bentuk desain penilaian pembelajaran PAI yang digunakan di SMA Negeri 4 Palopo berbasis kurikulum 2013 dan dirumuskan bersama di forum MGMP. Kualifikasi guru sudah sesuai dengan latar belakang pendidikan namun kompetensi pedagogik sebagaian guru masih kurang maksimal dan faktor penunjang sudah ada namun kurang memadai. Evaluasi terhadap input, dukungan sekolah dan usaha guru masih kurang maksimal. Evaluasi process, pemanfaatan desain penilaian pembelajaran PAI belum sesuai. Evaluasi product, pemanfaatan desain penilaian pembelajaran PAI menimbulkan dampak positif bagi guru maupun siswa serta respon siswa menimbulkan respon negatif. ${ }^{5}$

Desain pembelajaran sangat diperlukan untuk menjadikan pembelajaran lebih efektif dan efesien. Pembelajaran efektif adalah pembelajaran yang mencakup 4 dimensi. Pertama, context (situasi/latar belakang yang mempengaruhi tujuan dan strategi yang dikembangkan. Misalnya berupa kebijakan departemen atau sasaran yang ingin dicapai oleh unit kerja. Kedua, input (mencakup bahan, peralatan dan fasilitas yang disiapkan untuk keperluan program. Misalnya dokumen, kurikulum, staf pengajar, media pembelajaran dan lain sebagainya). Ketiga, process (pelaksanaan yang nyata dari program pendidikan di kelas/lapangan), Keempat, product (Merupakan hasil keseluruhan yang dicapai oleh program yang tujuan utamanya adalah untuk meningkatkan kompetensi siswa). ${ }^{6}$ Pembelajaran efesien adalah pembelajaran yang dapat menghasilkan peningkatan kualitas belajar dan penguasaan materi belajar, mempersingkat waktu belajar, meningkatkan kemampuan guru, mengurangi biaya tanpa mengurangi kualitas belajar mengajar. ${ }^{7}$

\footnotetext{
${ }^{4}$ Deby Arisma, Evaluasi Program Pendidikan Sistem Ganda di Sekolah Menengah Kejuruan Melalui Model CIPP (Studi Kasus Di SMK Bhineka Karya Surakarta Jurusan Otomatif), Tesis, (Surakarta: Prodi Tehnologi Pendidikan Universitas Sebelas Maret Surakarta,2013), h. 113.

5Junita, Evaluasi Program Desain Penilaian Pembelajaran Pendidikan Agama Islam Melalui Model Context, Input, Process, Product di SMA Negeri 4 Palopo, Tesis, (Palopo: Prodi Manajemen Pendidikan Islam Institut Agama Islam Negeri Palopo, 2016), h. 118.

${ }^{6}$ Oemar Hamalik, Kurikulum dan Pembelajaran. (Jakarta: Bumi Aksara,2002), h. 8.

${ }^{7}$ Baharudin dan Wahyuni, Teori Belajar dan Pembelajaran, (Yogyakarta: Ar-Ruz Media, 2007), h. 15.
} 


\section{Metode}

Penelitian ini merupakan penelitian lapangan dengan desain penelitian kualitatif. Pendekatan yang digunakan adalah pendekatan manajemen yaitu: perencanaan, pengorgnisasian, pengarahan dan implementasi dan pengawasan. Subjek penelitian ini adalah kepala sekolah, guru pendidikan agama Islam, dan peserta didik. Teknik pengumpulan data yang digunakan dalam penelitian ini adalah teknik wawancara, observasi, dan dokumentasi. ${ }^{8}$ Dalam penelitian ini, instrumen utamanya adalah peneliti sendiri untuk menetapkan fokus penelitian, memilih informan sebagai sumber data, melakukan pengumpulan data, menilai kualitas data, analisis data, menafsirkan data dan membuat kesimpulan atas temuannya. ${ }^{9}$ Dan adapun instrumen pendukung yaitu pedoman wawancara, pedoman observasi dan field note (catatan lapangan). Data yang terkumpul dianalisis secara kualitatif dengan menggunakan pendekatan logika induktif, dimana silogisme dibangun berdasarkan pada hal-hal khusus atau data di lapangan dan bermuara pada kesimpulan-kesimpulan umum.

\section{Evaluasi Konteks (Context) Desain Pembelajaran PAI}

Aspek konteks mencakup masalah yang berkaitan dengan bentuk desain pembelajaran PAI, proses penyusunan desain pembelajaran PAI, tujuan pembuatan desain pembelajaran PAI, persyaratan (kompetensi dan kualifikasi) guru dalam membuat desain pembelajaran dan faktor penunjang penyusunan desain pembelajaran PAI di SMA Negeri 4 Palopo. Berikut ini hasil penelitian evaluasi konteks desain pembelajaran PAI di SMA Negeri 4 Palopo:

1) Berdasarkan hasil wawancara peneliti kepada semua guru Pendidikan Agama Islam di SMA Negeri 4 Palopo, peneliti menemukan data tentang bentuk desain pembelajaran PAI yang digunakan dalam proses pembelajaran tahun pelajaran 2016/2017 yaitu menggunakan desain pembelajaran PAI berbasis Kurikulum 2013.10 Hal ini dibuktikan dengan hasil observasi peneliti pada saat mengunjungi kelas yang sedang berlangsung pada setiap guru Pendidikan Agama Islam, peneliti menemukan data bahwa mereka dalam melaksanakan proses pembelajaran menggunakan desain pembelajaran PAI berbasis kurikulum 2013.11 Kemudian berdasarkan hasil dokumentasi, peneliti menemukan data bahwa di antara ketiga guru Pendidikan Agama Islam tersebut, terdapat 1 guru yang memiliki desain pembelajaran PAI berbasis kurikulum 2013 masih dalam bentuk file, kemudian 1 guru yang memiliki perangkat desain pembelajaran yang tidak lengkap, dia hanya memiliki program tahunan, program semester, silabus, dan RPP untuk 3 kali pertemuan saja dan terdapat 1 guru yang memiliki

\footnotetext{
8Sugiyono, Metode Penelitian Pendidikan, Pendekatan Kuantitatif \& Kualitatif, (Bandung: Alfabeta, 2012), h.83.

9Sugiyono, Memahami Penelitian Kualitatif, (Bandung: Alfababeta, 2012), h. 62.

${ }^{10}$ Munasar, Sintang kasim, dan Sari bunga, Guru mata pelajaran PAI di SMA Negeri 4 Palopo, Wawancara, tanggal 21 April 2016.

11 Observasi di SMA Negeri 4 Palopo, tanggal 22 April 2016.
} 


\section{2 | Nur Amalina}

desain pembelajaran yang cukup lengkap walaupun rencana pelaksanaan pembelajaran (RPP) belum selesai dibuat. ${ }^{12}$

2) Berdasarkan hasil wawancara peneliti kepada semua guru Pendidikan Agama Islam di SMA Negeri 4 Palopo, peneliti menemukan data bahwa proses penyusunan desain pembelajaran PAI (program tahunan, program semester, dan silabus) dirumuskan secara bersama pada forum musyawarah guru mata pelajaran (MGMP) selanjutnya penyusunan desain pembelajaran PAI (RPP) dilakukan secara individu di setiap sekolah yang disesuaikan dengan keadaan sekolah masing-masing. ${ }^{13}$ Namun, kenyataannya berdasarkan hasil observasi peneliti menemukan data bahwa dalam proses penyusunan desain pembelajaran

PAI mengabaikan kondisi sekolah yaitu sekolah tidak memiliki media pembelajaran yang dibutuhkan seperti LCD atau powerpoint materi pembelajaran. ${ }^{14}$

3) Berdasarkan hasil wawancara peneliti kepada semua guru Pendidikan Agama Islam di SMA Negeri 4 Palopo, peneliti menemukan data bahwa tujuan penyusunan desain pembelajaran PAI di SMA Negeri 4 Palopo seperti yang dikemukakan oleh Sintang Kasim, guru mata pelajaran Pendidikan Agama Islam kelas X, beliau mengatakan bahwa "Perangkat pembelajaran PAI (Program tahunan, program semester, silabus dan RPP) dibuat dengan tujuan melengkapi administrasi pembelajaran, sebagai alat ukur efektif tidaknya suatu proses pembelajaran/tugas guru ,dan tentunya bertujuan juga untuk membantu guru dalam memandu proses pembelajaran agar proses pembelajaran dapat berlangsung secara efesien yaitu guru dapat menghemat waktu dan tenaga". ${ }^{15}$

4) Berdasarkan hasil wawancara peneliti kepada semua guru Pendidikan Agama Islam di SMA Negeri 4 Palopo, peneliti menemukan data bahwa persyaratan (kompetensi dan kualifikasi) guru dalam membuat desain pembelajaran PAI sudah sesuai dengan kualifikasi mereka masingmasing sebagai guru Pendidikan Agama Islam dan latar belakang pendidikan yang berasal dari pendidikan guru Pendidikan Agama Islam. ${ }^{16}$ Selanjutnya berdasarkan data hasil observasi mengenai kompetensi guru Pendidikan Agama Islam masih kurang maksimal khususnya kompetensi pedagogik yang berkaitan dengan kemampuan guru dalam merancang desain pembelajaran dan melaksanakan proses pembelajaran karena guru jarang sekali mengikuti pelatihan-pelatihan/workshop-workhsop hal ini disebabkan oleh kemampuan sekolah menyediakan dana yang tidak maksimal. Kondisi ini berimbas kepada kewajiban guru dalam membuat desain pembelajaran PAI yaitu guru cenderung tidak memperhatikan kondisi sekolah pada saat membuat desain

\footnotetext{
12Dokumentasi di SMA Negeri 4 Palopo, tanggal 22 April 2016.

13 Munasar, Sintang kasim, dan Sari Bunga, Guru mata pelajaran PAI di SMA Negeri 4 Palopo, Wawancara, tanggal 21 April 2016.

14 Observasi di SMA Negeri 4 Palopo, tanggal 22 April 2016.

${ }^{15}$ Sintang Kasim, Guru mata pelajaran PAI kelas X SMA Negeri 4 Palopo, Wawancara, tanggal 23 April 2016.

16Munasar, Sintang kasim, dan Sari bunga, Guru mata pelajaran PAI di SMA Negeri 4 Palopo, Wawancara, tanggal 23 April 2016.
} 
pebelajaran PAI dan terkadang juga guru hanya menyalin file perangkat pembelajaran dari guru-guru yang lain. ${ }^{17}$

5) Data mengenai faktor penunjang pembuatan desain pembelajaran PAI di SMA Negeri 4 Palopo dapat diketahui melalui hasil wawancara peneliti kepada semua guru Pendidikan Agama Islam di SMA Negeri 4 Palopo. Berikut ini kutipan hasil wawancara peneliti kepada Munasar dan Sari Bunga yaitu "Dalam hal pembuatan semua administrasi pembelajaran, sekolah selalu menyediakan kertas dan printer yang bisa diperoleh ruangan tata usaha, walaupun terkadang guru biasanya membawa tinta sendiri". ${ }^{18}$ Hal ini dibuktikan dengan data hasil observasi dan data hasil studi dokumentasi peneliti bahwa di ruang tata usaha telah sediakan kertas dan printer untuk guru-guru yang akan membuat desain pembelajaran. ${ }^{19}$

\section{Evaluasi Masukan (Input) Desain Pembelajaran PAI}

Aspek input mencakup masalah yang berkaitan dengan dukungan sekolah dalam penyusunan desain pembelajaran PAI dan usaha guru dalam menyusun desain pembelajaran PAI di SMA Negeri 4 Palopo. Berikut ini hasil penelitian evaluasi input desain pembelajaran PAI di SMA Negeri 4 Palopo:

1) Data tentang dukungan sekolah dalam penyusunan desain pembelajaran PAI dapat diketahui melalui data hasil wawancara peneliti kepada Wakasek Kurikulum SMA Negeri 4 Palopo dan guru Pendidikan Agama Islam. Kadir selaku Wakasek Kurikulum SMA Negeri 4 Palopo, mengatakan bahwa "Sebenarnya sekolah selalu mendukung pembuatan desain pembelajaran PAI dengan cara mengikutkan guru-guru untuk mengikuti forum MGMP yang diadakan di luar sekolah walaupun masih kurang maksimal karena kemampuan sekolah untuk membiayai guru-guru mengikuti forum MGMP masih kekurangan dana akibatnya guru hanya secara bergantian mengikuti forum MGPM tersebut selain itu dukungan sekolah dalam pembuatan desain pembelajaran PAI yaitu sekolah menyediakan kertas dan printer yang bisa diperoleh oleh guru di di ruang tata usaha SMA Negeri 4 Palopo. ${ }^{20}$ Berikut kutipan hasil wawancara kepada guru Pendidikan Agama Islam, Sari Bunga, guru PAI kelas XI mengatakan bahwa "Sebenarnya sekolah menyediakan fasilitas berupa kertas untuk pembuatan desain pembelajaran namun selama ini saya merasa kertas yang disediakan sekolah itu tidak mencukupi karena masih ada guru-guru yang menyediakan kertas sendiri dan termasuk saya selama ini menyediakan kertas sendiri dan printer untuk pembuatan desain pembelajaran PAI". ${ }^{21}$

2) Berdasarkan hasil wawancara peneliti kepada semua guru Pendidikan Agama Islam di SMA Negeri 4 Palopo, peneliti menemukan data

\footnotetext{
17Observasi di SMA Negeri 4 Palopo, tanggal 25 April 2016.

18Sari Bunga dan Munasar, Guru mata pelajaran PAI kelas XI dan kelas XII SMA Negeri 4 Palopo, Wawancara, tanggal 23 April 2016.

19 Observasi dan dokumentasi di SMA Negeri 4 Palopo, tanggal 25 April 2016.

20 Kadir, Wakasek Kurikulum SMA Negeri 4 Palopo, Wawancara, tanggal 02 Mei 2016.

${ }^{21}$ Sari Bunga, Guru mata pelajaran PAI kelas XI SMA Negeri 4 Palopo, Wawancara, tanggal 02 Mei 2016.
} 


\section{4 | Nur Amalina}

bahwa usaha guru dalam membuat desain pembelajaran PAI masih kurang maksimal, seperti yang di kemukakan oleh Munasar guru Pendidikan Agama Islam kelas XII, beliau mengatakan bahwa "Usaha guru dalam membuat desain pembelajaran PAI sebenarnya masih kurang maksimal karena sekolah tidak pernah mengadakan workshop/pelatihan untuk guru-guru dalam membuat desain pembelajaran, kemudian sekolah ini tidak membentuk forum MGMP sebagaimana sekolah lainnya, dan guru yang biasanya akan mengikuti forum MGMP di luar terkendala dana akibatnya sekolah membatasi perwakilan guru yang akan mengikuti forum MGMP di luar". ${ }^{22}$

\section{Evaluasi Proses (Process) Desain Pembelajaran PAI}

Aspek proses mencakup masalah yang berkaitan dengan kesesuaian pemanfaatan desain pembelajaran PAI dalam proses pembelajaran PAI, waktu penyusunan desain pembelajaran PAI dan masa pemanfaatan desain pembelajaran PAI dalam proses pembelajaran PAI di SMA Negeri 4 Palopo. Berikut ini hasil penelitian evaluasi input desain pembelajaran PAI di SMA Negeri 4 Palopo:

1) Berdasarkan hasil observasi peneliti kepada semua guru Pendidikan Agama Islam di SMA Negeri 4 Palopo, peneliti menemukan data bahwa pemanfaatan desain pembelajaran yang telah dibuat sebelumnya terkadang sesuai dan juga tidak sesuai dengan apa yang telah tertulis di desain pembelajaran. Misalnya hasil observasi awal di kelas $\mathrm{X}_{3}$ proses pembelajaran yang berlangsung telah sesuai dengan desain pembelajaran yang telah dibuat sebelumnya yaitu guru mengajarkan materi yang telah tertera di desain pembelajaran. Hal ini membuat penyampaian materi terstruktur dan siswa juga senang karena materi yang akan diajarkan terdapat di buku cetak masing-masing. Selain itu guru juga menggunakan metode mengajar yang sesuai dengan materi, seperti metode diskusi dan tanya jawab, jadi guru dapat memaksimalkan waktu dalam proses pembelajaran. ${ }^{23}$ Namun observasi kedua di kelas $\mathrm{X}_{2}$ proses pembelajaran yang sedang berlangsung tidak berjalan dengan maksimal dan melenceng dari desain pembelajaran karena materinya yang diajarkan membutuhkan perangkat pembelajaran elektronik seperti LCD namun sekolah tidak mempunyai alat tersebut untuk menampilkan Powerpoint Unit 1 Facil Advance Learning Islamic Education and Moral Values 1 for Grade X. Jadi, guru hanya sekedar menjelaskan saja materinya secara singkat dan dilanjutkan dengan mengecek hafalan sholat siswa-siswinya. ${ }^{24}$

2) Berdasarkan hasil wawancara peneliti kepada semua guru Pendidikan Agama Islam di SMA Negeri 4 Palopo, peneliti menemukan data bahwa waktu pembuatan desain pembelajaran PAI dilakukan di setiap awal

22 Munasar, Guru mata pelajaran PAI Kelas XII SMA Negeri 4 Palopo, Wawancara, tanggal 02 Mei 2016.

23 Observasi di SMA Negeri 4 Palopo, tanggal 03 Mei 2016.

${ }^{24}$ Observasi di SMA Negeri 4 Palopo, tanggal 03 Mei 2016. 
semester. ${ }^{25}$ Namun berdasarkan hasil observasi, peneliti menemukan bahwa semua guru Pendidikan Agama Islam di SMA Negeri 4 Palopo memang mereka membuat desain pembelajaran PAI di awal semester namun itu hanya program semester dan silabus. RPP juga dibuat di awal semester namun itu belum selesai untuk keperluan satu semester, biasanya mereka membuat hanya untuk beberapa pertemuan saja dan akan dilengkapi apabila supervisor akan datang ke sekolah, hal ini terjadi karena guru Pendidikan Agama Islam menganggap bahwa pembelajaran yang nanti akan dibawakan sudah dikuasai karena sudah terulang-ulang disetiap semesternya. ${ }^{26}$

3) Berdasarkan hasil wawancara peneliti kepada semua guru Pendidikan Agama Islam di SMA Negeri 4 Palopo, peneliti menemukan data bahwa masa pemanfaatan desain pembelajaran PAI berlaku satu semester. ${ }^{27}$ Hal ini dibuktikan dengan hasil observasi, peneliti menemukan bahwa pada setiap pergantian semester maka seluruh desain pembelajaran di semester sebelumnya tidak digunakan lagi dan akan membuat desain pembelajaran yang sesuai dengan semester berjalan. ${ }^{28}$

\section{Evaluasi Hasil (Product) Desain Pembelajaran PAI}

Aspek product mencakup masalah yang berkaitan dengan dampak pemanfaatan desain pembelajaran PAI dan respon siswa terhadap pemanfaatan desain pembelajaran PAI di SMA Negeri 4 Palopo. Berikut ini hasil penelitian evaluasi input desain pembelajaran PAI di SMA Negeri 4 Palopo:

1) Berdasarkan hasil observasi peneliti pada saat proses pembelajaran berlangsung di SMA Negeri 4 Palopo, peneliti menemukan data bahwa terdapat dampak positif dan dampak negatif yang dihasilkan oleh pemanfaatan desain pembelajaran PAI di SMA Negeri 4 Palopo. Dampak positif yang dimaksud yaitu, "Suasana proses pembelajaran dengan pemanfatan desain pembelajaran sangat menguntungkan bagi guru maupun siswa karena guru dapat memanfaatkan waktu pembelajaran dengan maksimal yaitu guru hanya berfokus pada materi yang telah tercantum pada perangkat pelaksanaan pembelajaran. Hal ini yang akan membuat penyampaian materi pelajaran akan terstruktur dan pada akhirnya siswa juga senang karena materi yang akan diajarkan terdapat di buku cetak masing-masing". ${ }^{29}$ Adapun dampak negatif yang dimaksud yaitu, "Suasana pembelajaran tidak berjalan dengan maksimal karena materinya yang akan diajarkan membutuhkan perangkat pembelajaran elektronik seperti LCD namun sekolah tidak mempunyai alat tersebut untuk menampilkan Powerpoint Unit 1 Facil Advance Learning Islamic Education and Moral

25Munasar, Sintang Kasim, dan Sari Bunga, Guru mata pelajaran PAI di SMA Negeri 4

Palopo, Wawancara, tanggal 02 Mei 2016.

260bservasi di SMA Negeri 4 Palopo, tanggal 11 Mei 2016.

${ }^{27}$ Munasar, Sintang Kasim, dan Sari Bunga, Guru mata pelajaran PAI di SMA Negeri 4

Palopo, Wawancara, tanggal 10 Mei 2016.

28Observasi di SMA Negeri 4 Palopo, tanggal 10 Mei 2016.

${ }^{29}$ Observasi di SMA Negeri 4 Palopo, tanggal 10 Mei 2016. 


\section{6 | Nur Amalina}

Values 1 for Grade X. Jadi, guru hanya sekedar menjelaskan saja materinya secara singkat dan dilanjutkan dengan mengecek hafalan sholat siswasiswinya". ${ }^{0}$ Disamping itu juga "Suasana proses pembelajaran dengan pemanfaatan desain pembelajaran terkesan monoton dan tidak membuat proses pembelajaran lebih aktif, karena guru kurang memanfaatkan metode pembelajaran yang sesuai dengan materi yang diajarkan yaitu guru hanya menyampaikan materi pelajaran dengan metode ceramah saja". ${ }^{31}$

2) Berdasarkan hasil wawancara peneliti pada sejumlah siswa di SMA Negeri 4 Palopo, peneliti menemukan data bahwa terdapat respon positif dan negatif siswa terhadap pemanfaatan desain pembelajaran PAI di SMA Negeri 4 Palopo. Dampak positif yang dimaksud yaitu, "Saya lebih antusias dan senang karena materi yang akan di sampaikan oleh guru sudah terdapat dibuku cetak. Jadi, ini sangat memudahkan saya dalam mengikuti proses pembelajaran".32 "Saya merasa lebih fokus dalam mengikuti proses pembelajaran karena saya siswa sudah siap dengan al-Qur'an dan terjemahannya, jadi materi yang dipelajari dapat saya pahami dengan baik". ${ }^{33}$ Adapun respon negatif yang dimaksud yaitu, "Saya merasa bahwa pembelajaran yang berlangsung sangat kurang maksimal karena guru hanya menjelaskan secara singkat materi yang dipelajari alasannya karena tidak adanya LCD yang akan digunakan untuk menampilkan power point jadi kebanyakan waktu digunakan untuk mengecek hafalan sholat saja". ${ }^{34}$ "Saya merasa bosan dan bahkan terdapat biasanya saya mengantuk dalam mengikuti proses pembelajaran karena dalam guru menyampaikan materi pelajaran selalu menggunakan metode ceramah saja tanpa memberikan kesempatan kepada saya untuk menanyakan materi yang kurang saya pahami". ${ }^{35}$

\section{Pembahasan Evaluasi Konteks (Context) Desain Pembelajaran PAI}

Berdasarkan hasil wawancara, observasi dan studi dokumentasi, peneliti menemukan data bahwa guru-guru PAI di SMA Negeri 4 Palopo menggunakan bentuk desain pembelajaran PAI berbasis kurikulum 2013. Dalam proses pembelajaran telah dipahami bahwa keberadaan desain pembelajaran itu sangat di perlukan sebagai pedoman kerja bagi setiap unsur, baik itu unsur guru maupun unsur murid. Jadi, bentuk desain pembelajaran harus sesuai dengan konsep kurikulum yang digunakan di sekolah tersebut. Kurikulum khususnya silabus harus menjadi acuan utama dalam penyusunan desain pembelajaran namun kondisi sekolah dan

\footnotetext{
30Observasi di SMA Negeri 4 Palopo, tanggal 11 Mei 2016.

${ }^{31}$ Observasi di SMA Negeri 4 Palopo, tanggal 11 Mei 2016.

${ }^{32}$ Desi kartika sari, siswa kelas $\mathrm{X}_{3}$ SMA Negeri 4 Palopo, Wawancara, tanggal 17 Mei
}

2016.

${ }^{33}$ Delsi kartika putri, siswa kelas $\mathrm{XI}_{2}$ SMA Negeri 4 Palopo, Wawancara, tanggal 17 Mei 2016.

${ }^{34}$ Atika, siswa kelas $\mathrm{X}_{3}$ SMA Negeri 4 Palopo, Wawancara, tanggal 17 Mei 2016.

35Fatimah, siswa kelas XI 4 SMA Negeri 4 Palopo, Wawancara, tanggal 18 Mei 2016. 
lingkungan sekitar, kondisi siswa dan guru merupakan hal yang penting jangan sampai diabaikan.

Selanjutnya proses penyusunan desain pembelajaran PAI dapat diketahui melalui hasil wawancara yaitu perangkat pembelajaran PAI terlebih dahulu dirumuskan secara bersama pada forum musyawarah guru mata pelajaran (MGMP) kemudian selanjutnya penyusunan RPP dilakukan secara individu di setiap sekolah yang disesuaikan dengan keadaan sekolah masing-masing. Namun, kenyataannya berdasarkan hasil observasi peneliti menemukan data bahwa dalam proses penyusunan desain pembelajaran PAI mengabaikan kondisi sekolah yaitu sekolah tidak memiliki media pembelajaran yang dibutuhkan seperti LCD atau powerpoint materi pembelajaran akibatnya guru cenderung menyampaikan secara singkat saja materi yang terdapat dalam desain pembelajaran tersebut. Hal ini juga disebabkan karena guru hanya menyalin file RPP dari guru-guru lainnya.

Pada umumnya para guru telah membuat desain pembelajaran akan tetapi masih ada yang belum memenuhi ketentuan standar proses. Misalnya guru masih menggunakan desain pembelajaran yang belum disesuaikan dengan kondisi sekolah dan kebutuhan peserta didik di satuan pendidikan. Desain pembelajaran idealnya dibuat oleh guru itu sendiri, karena gurulah yang lebih tahu kondisi dan situasi, kelebihan dan kekurangan yang dimiliki peserta didik, dan sekolah. Desain pembelajaran merupakan persiapan yang harus dilakukan guru sebelum mengajar. Jadi, guru dalam proses membuat desain pembelajaran harus mempertimbangkan kondisi sekolah, kondisi peserta didik serta kemampuan guru dalam menjabarkan menjadi rencana pelaksanaan pembelajaran yang siap dijadikan pedoman pembentukan kompetensi peserta didik. Agar guru dapat membuat desain pembelajaran yang efektif dan berhasil guna, guru dituntut untuk memahami berbagai aspek yang berkaitan dengan hakikat, fungsi, prinsip dan prosedur pengembangan, serta cara mengukur evektivitas pelaksanaannya dalam pembelajaran.

Mengenai tentang tujuan pembuatan desain pembelajaran PAI di SMA Negeri 4 Palopo dapat dilihat dan dipahami melalui hasil wawancara dengan beberapa guru PAI yaitu desain pembelajaran PAI dibuat dengan tujuan melengkapi administrasi pembelajaran, sebagai alat ukur efektif tidaknya suatu proses pembelajaran/tugas guru, dan tentunya bertujuan juga untuk membantu guru dalam memandu proses pembelajaran agar proses pembelajaran dapat berlangsung secara efesien yaitu guru dapat mengemat waktu dan tenaga.

Berdasarkan hasil wawancara tersebut dapat dipahami bahwa desain pembelajaran memainkan peran penting dalam peningkatan kualitas pembelajaran, hal ini dimungkinkan karena dengan merancang desain pembelajaran, seorang desainer (dalam hal ini guru) memiliki peran penting dalam merumuskan tujuan pembelajaran yang ingin dicapai. Dengan memiliki kesadaran akan pentingnya tujuan pembelajaran, maka guru akan berupaya untuk melakukan berbagai aktifitas dalam rangka mewujudkan tujuan pembelajaran, seperti merumuskan bahan instruksional, memilih strategi instruksional, memilih media dan alat pembelajaran, merancang alat 


\section{8 | Nur Amalina}

evaluasi, dan lain sebagainya. Hal ini sejalan yang dikatakan oleh St. Marwiyah, dalam bukunya Perencanaan pembelajaran Pendidikan Agama Islam, beliau mengemukakan bahwa manfaat membuat perencanaan pembelajaran khususnya desain pembelajaran adalah sebagai petunjuk arah kegiatan dalam mencapai tujuan, sebagai pedoman kerja bagi setiap unsur, baik unsur guru maupun unsur siswa, sebagai alat ukur efektif tidaknya suatu pekerjaan, dan untuk menghemat waktu, tenaga, alat-alat, dan biaya.

Mengenai persyaratan (kompetensi dan kualifikasi) guru dalam menyusun desain pembelajaran PAI di SMA Negeri 4 Palopo dapat dilihat dan dipahami melalui hasil wawancara dan observasi peneliti kepada semua guru Pendidikan Agama Islam di SMA Negeri 4 Palopo, peneliti menemukan data bahwa persyaratan (kompetensi dan kualifikasi) guru dalam membuat desain pembelajaran PAI sudah sesuai dengan kualifikasi mereka masingmasing sebagai guru Pendidikan Agama Islam dan latar belakang pendidikan yang berasal dari pendidikan guru Pendidikan Agama Islam.

Untuk menghasilkan desain pembelajaran PAI yang baik tentunya diperlukan kompetensi guru yang memadai karena kompetensi guru merupakan kemampuan seseorang guru dalam melaksanakan kewajibankewajiban secara bertanggung jawab dan layak. Kompetensi dan kualifikasi guru dijelaskan dalam Peraturan Pemerintah Nomor 19 Tahun 2005 Pasal 28 dijelaskan bahwa pendidik harus memiliki kualifikasi akademik dan kompetensi sebagai agen pembelajaran, sehat jasmani dan rohani, serta memiliki kemampuan untuk mewujudkan tujuan pendidikan nasional. Kualifikasi akademik adalah tingkat pendidikan minimal yang harus dipenuhi oleh seorang pendidik yang dibuktikan dengan ijazah atau sertifikat keahlian yang relevan sesuai ketentuan perundang-undangan yang berlaku. Kompetensi sebagai agen pembelajaran pada jenjang pendidikan dasar dan menengah serta pendidikan anak usia dini meliputi: meliputi kompetensi pedagogik, kompetensi kepribadian, kompetensi profesional dan kompetensi sosial. ${ }^{36}$

Namun hal ini tidak sejalan dengan keadaan guru PAI di SMA Negeri 4 Palopo, khususnya mengenai kompetensi pedagogik guru PAI, yaitu kemampuan guru dalam merancang pembelajaran khususnya membuat desain pembelajaran masih kurang maksimal hal ini disebabkan karena guru jarang sekali mengikuti pelatihan-pelatihan/workshop-workshop karena keterbatasan kemampuan sekolah menyediakan fasilitas (dana) yang tidak maksimal. Jadi, guru dalam menyusun desain pembelajaran PAI (RPP) cenderung lebih menyalin dari guru-guru yang lain akibatnya desain pembelajaran tersebut terkadang mengabaikan kondisi sekolah.

Adapun mengenai faktor penunjang penyusunan desain pembelajaran PAI di SMA Negeri 4 Palopo dapat diketahui melalui hasil wawancara, observasi dan studi dokumentasi yaitu peneliti menemukan data bahwa faktor penunjang penyusunan desain pembelajaran PAI di SMA Negeri 4 Palopo yaitu adanya fasilitas yang disediakan oleh sekolah seperti kertas, komputer dan printer. Hal ini dibuktikan dengan hasil observasi dan hasil

36Hilal Mahmud, Administrasi Pendidikan (Menuju Sekolah Efektif), (Makassar: Akasara Timur, 2015), h.37. 
studi dokumentasi peneliti bahwa di ruang tata usaha telah sediakan kertas, komputer dan printer untuk para guru-guru yang akan membuat desain pembelajaran walaupun terkadang sarana yang telah disediakan belum terlalu memadai untuk para guru-guru. Berdasarkan Peraturan Pemerintah Nomor 19 tahun 2005 Pasal 42, secara tegas dijelaskan bahwa setiap satuan pendidikan wajib memiliki sarana yang meliputi perabot, peralatan pendidikan, media pendidikan, buku dan sumber belajar lainnya, bahan habis pakai serta pelengkap lain yang diperlukan untuk menunjang proses pembelajaran yang teratur dan berkelanjutan ${ }^{37}$. Dengan demikian sekolah harus bisa memenuhi seluruh kebutuhan untuk menunjang proses pembelajaran agar proses pembelajaran dapat terlaksana secara optimal.

\section{Pembahasan Evaluasi Masukan (Input) Desain Pembelajaran PAI}

Berdasarkan hasil wawancara, observasi dan studi dokumentasi, peneliti menemukan data bahwa dukungan sekolah dalam menyusun desain pembelajaran PAI yaitu sekolah menyediakan fasilitas berupa komputer, kertas dan printer untuk penyusunan desain pembelajaran PAI walaupun terkadang jumlah kertas dan printer masih kurang sehingga masih terdapat guru yang menyediakan sendiri. Adapun dukungan sekolah yang lain dapat diketahui melalui hasil wawancara kepada Wakasek Kurikulum SMA Negeri 4 Palopo yaitu dalam hal penyusunan desain pembelajaran, sekolah selalu mendukung dengan cara mengikutsertakan guru-guru dalam forum MGMP walaupun guru-guru harus bergantian mengikuti forum MGMP karena kemampuan sekolah dalam menyediakan dana masih kurang maksimal.

Dalam proses penyusunan desain pembelajaran PAI tentunya tidak terlepas dari dukungan dari sekolah itu sendiri dan usaha guru dalam membuatnya. Pentingnya dukungan sekolah dalam hal menyediakan sarana penunjang pembuatan desain pembelajaran PAI juga dijelaskan dalam Peraturan Pemerintah Nomor 19 tahun 2005 Pasal 42, secara tegas dijelaskan bahwa setiap satuan pendidikan wajib memiliki sarana yang meliputi perabot, peralatan pendidikan, media pendidikan, buku dan sumber belajar lainnya, bahan habis pakai serta pelengkap lain yang diperlukan untuk menunjang proses pembelajaran yang teratur dan berkelanjutan. ${ }^{38}$ Dalam proses belajar mengajar, sarana pembelajaran sangat membantu siswa untuk mencapai tujuan pembelajaran karena sarana pembelajaran memudahkan terjadinya proses pembelajaran. Oleh sebab itu sekolah harus bisa bekerja sama dengan guru dalam menyediakan sarana pembelajaran yang dibutuhkan selain itu untuk mewujudkan proses pembelajaran yang berkualitas tentunya guru harus selalu berusaha untuk meningkatkan kompetensinya. Salah satu wadah peningkatan kompetensi guru yaitu forum musnyawarah guru mata pelajaran (MGMP). Jadi, berdasarkan pemaparan tersebut sekolah seharusnya lebih maksimal dalam memberikan dukungan kepada guru-guru.

${ }^{37}$ Barnawi \& M. Arifin, Manajemen Sarana \& Prasarana Sekolah, (Jogyakarta: Ar-Ruzz Media, 2012), h. 85.

38Barnawi \& M. Arifin, Manajemen Sarana \& Prasarana Sekolah, h. 85. 
Mengenai usaha guru dalam menyusun desain pembelajaran PAI di SMA Negeri 4 Palopo dapat diketahui melalui hasil wawancara kepada beberapa responden peneliti menemukan data bahwa usaha guru dalam membuat desain pembelajaran PAI sebenarnya masih kurang maksimal karena sekolah tidak pernah mengadakan workshop/pelatihan untuk guruguru dalam membuat desain pembelajaran, kemudian sekolah ini tidak membentuk forum MGMP sebagaimana sekolah lainnya, dan guru yang biasanya akan mengikuti forum MGMP di luar terkendala dana akibatnya sekolah membatasi perwakilan guru yang akan mengikuti forum MGMP di luar.

Dalam proses pembelajaran, guru memegang peranan yang sangat penting, sebab keberhasilan pelaksanaan proses pendidikan sangat tergantung pada guru. Jadi, sebaiknya sekolah harus bisa mendukung usaha guru dalam meningkatkan kompetensinya diantaranya mengadakan pelatihan-pelatihan di sekolah dan memaksimalkan kemampuan sekolah dalam menyediakan dana sebab kualitas sebuah lembaga pendidikan tergantung dari pada kualitas guru yang dimilikinya.

\section{Pembahasan Evaluasi Proses (Process) Desain Pembelajaran PAI}

Berdasarkan hasil penelitian yang telah dikemukakan sebelumnya, peneliti menemukan data bahwa kesesuaian pemanfaatan desain pembelajaran PAI dalam proses pembelajaran PAI terkadang sesuai dan juga terkadang tidak sesuai dengan apa yang telah tertulis di desain pembelajaran. Hal ini disebabkan karena minimnya fasilitas media pembelajaran elektronik di kelas, kelalaian siswa tidak membawa buku cetak/media pendukung pembelajaran yang lain, dan faktor pemilihan metode pembelajaran yang terkadang tidak tepat dengan materi pelajaran.

Desain pembelajaran yang telah dibuat sebaiknya dapat dimanfaatkan secara maksimal oleh guru, karena desain pembelajaran merupakan petunjuk bagi guru dalam melaksanakan proses pembelajaran. Pembelajaran yang lebih bermakna dan ideal apabila dilaksanakan sesuai dengan desain pembelajaran yang sebelumnya telah dibuat. Menciptakan proses pembelajaran yang lebih bermakna tentunya tidak terlepas dari guru, sumber belajar dan siswa ketiganya saling berkaitan satu sama lain oleh sebab itu guru memiliki peran yang sangat penting dalam menentukan kuantitas dan kualitas pengajaran yang dilaksanakannya khususnya dalam pembelajaran PAI. Guru berperan sebagai pengelola proses pembelajaran, bertindak selaku fasilitator yang berusaha menciptakan kondisi pembelajaran yang efektif, mengembangkan bahan pengajaran dengan baik dan meningkatkan kemampuan siswa untuk menyimak pelajaran dan menguasai tujuan-tujuan pendidikan yang harus mereka capai.

Mengenai waktu penyusunan desain pembelajaran PAI di SMA Negeri 4 Palopo dapat diketahui melalui hasil wawancara dan observasi. Peneliti menemukan data bahwa waktu penyusunan desain pembelajaran PAI dilakukan di setiap awal semester dengan maksud agar desain pembelajaran telah tersedia terlebih dahulu dalam setiap awal pelaksanaan pembelajaran. 
Namun berdasarkan hasil obeservasi, peneliti menemukan data bahwa semua guru Pendidikan Agama Islam di SMA Negeri 4 Palopo memang mereka membuat desain pembelajaran PAI di awal semester namun itu hanya program semester dan silabus. RPP juga dibuat di awal semester namun itu belum selesai untuk keperluan satu semester, biasanya mereka membuat hanya untuk beberapa pertemuan saja dan akan dilengkapi apabila supervisor akan datang ke sekolah, hal ini terjadi karena guru Pendidikan Agama Islam menganggap bahwa pembelajaran yang nanti akan dibawakan sudah dikuasai karena sudah berulang-ulang disetiap semesternya.

Tugas guru yang pertama adalah merencanakan pembelajaran. Perencanaan pembelajaran harus dibuat sebaik mungkin karena perencanaan yang baik akan membawa hasil yang baik pula. Guru wajib membuat desain pembelajaran pada awal tahun atau awal semester, sesuai dengan rencana kerja sekolah. Kegiatan pembuatan desain pembelajaran diperkirakan berlangsung selama dua minggu atau 12 hari kerja. Membuat desain pembelajaran merupakan kegiatan yang sangat penting dilakukan oleh setiap guru. Karena dalam desain pembelajaran memuat tentang tujuan dari pembelajaran yang mana setiap pokok bahasan akan memiliki tujuan yang berbeda. Selain itu desain pembelajaran juga memuat tetntang perencanaan bahan, perencanaan alat peraga, metode pengajaran dan prosedur-prosedur pembelajaran. Minimal dengan membuat desain pembelajaran guru akan tahu materi yang akan diajarkan siswa-siswinya esok hari dan guru juga harus membuat desain pembelajaran untuk setiap pertemuan yang disesuaikan dengan penjadwalan disatuan pendidikan.

Adapun mengenai masa pemanfaatan desain pembelajaran PAI di SMA Negeri 4 Palopo peneliti menemukan data bahwa masa pemanfaatan desain pembelajaran PAI belaku 1 semester. Hal ini dibuktikan dengan hasil observasi, peneliti menemukan bahwa pada setiap pergantian semester maka seluruh desain pembelajaran PAI di semester sebelumnya tidak digunakan lagi dan akan membuat desain pembelajaran PAI yang sesuai dengan semester berjalan. Hal ini dimaksudkan agar nantinya proses pembelajaran yang akan berlangsung secara optimal dapat ditunjang dengan perangkat pembelajaran yang sesuai dengan kebutuhan dan kondisi sekolah setempat dan menghindari agar tidak terjadi kekacauan bagi guru dalam menjalankan tugasnya sebagai guru.

\section{Pembahasan Evaluasi Hasil (Product) Desain Pembelajaran PAI}

Berdasarkan hasil penelitian yang telah dikemukakan sebelumnya, peneliti menemukan data bahwa terdapat dampak positif dan dampak negatif yang dihasilkan oleh pemanfaatan desain pembelajaran PAI di SMA Negeri 4 Palopo. Dampak positif pemanfaatan desain pembelajaran PAI yang dimaksud adalah dengan pemanfatan desain pembelajaran sangat menguntungkan bagi guru maupun siswa karena guru dapat memanfaatkan waktu pembelajaran dengan maksimal yaitu guru hanya berfokus pada materi yang telah tercantum pada perangkat pelaksanaan pembelajaran. Selain itu pemanfatan desain pembelajaran membuat pembelajaran lebih 


\section{2 | Nur Amalina}

terarah dan dapat mencapai indikator yang telah di tentukan sebelumnya. Hal ini ditunjang dengan adanya komunikasi yang baik antara guru dan siswa yaitu pada pertemuan yang sebelumnya guru telah menyampaikan agar siswa-siswi membawa al-Qur'an dan Terjemahannya sebagai sumber pembelajaran. Pembelajaran pada hakekatnya adalah suatu proses interaksi antara peserta didik dengan sumber belajar pada suatu lingkungan belajar dan peserta didik dengan pendidik. Hal tersebut tertuang dengan jelas dalam Undang-undang Republik Indonesia Nomor 20 Tahun 2003 tentang sistem Pendidikan Nasional Pasal 1 dan Peraturan Pemerintah Nomor 17 tahun 2010 Pasal 1 tentang Pengelolaan dan Penyelenggaraan Pendidikan. Guru yang baik akan berusaha sedapat mungkin agar pembelajarannya berhasil dengan optimal dan memuaskan serta sesuai dengan yang diinginkan. Salah satu faktor yang bisa membawa keberhasilan itu adalah memanfaatkan desain pembelajaran dengan maksimal. Pemanfaatan desain pembelajaran secara maksimal dapat membuat pembelajaran berlangsung secara sistematis dan tentunya pembelajaran tidak akan berlangsung seadanya saja, tetapi akan terarah dan terorganisir dan guru dapat memanfaatkan waktu seefesien mungkin untuk mencapai tujuan pembelajaran. Pemanfaatan desain pembelajaran dengan maksimal juga dapat menciptakan pembelajaran yang efektif dan efesien dan hal yang tak kalah penting dalam upaya menciptakan pembelajaran yang efektif dan efesien adalah membangun komunikasi yang baik dengan siswa.

Adapun dampak negatif pemanfaatan desain pembelajaran PAI yang dimaksud adalah suasana pembelajaran tidak berjalan dengan maksimal karena materinya yang akan diajarkan membutuhkan perangkat pembelajaran elektronik seperti LCD namun sekolah tidak mempunyai alat tersebut untuk menampilkan powerpoint Unit 1 Facil Advance Learning Islamic Education and Moral Values 1 for Grade $X$, guru hanya sekedar menjelaskan saja materinya secara singkat dan dilanjutkan dengan mengecek hafalan sholat siswa-siswinya. Selain itu juga dampak negatif yang lain adalah suasana proses pembelajaran berjalan kurang efektif dan efesien karena kurangnya komunikasi antara guru dan siswa, jadi siswa tidak membawa salah satu sumber pembelajaran yaitu al-Qur'an dan Terjemahannya selain itu masih juga terdapat siswa yang tidak membawa buku cetaknya. Hal inilah yang mengakibatkan proses pembelajaran kurang maksimal, karena guru hanya menyinggung sedikit materi yang terdapat dalam desain pembelajaran selanjutnya guru memilih lebih banyak waktu pembelajaran untuk memastikan bacaan-bacaan sholat siswa-siswinya. Akibatnya pemanfaatan waktu dalam proses pembelajaran sangat tidak maksimal, karena siswa yang telah dicek bacaan-bacaan sholatnya dengan leluasa akan keluar masuk kelas atau bercerita dengan teman-temannya.

Guru dalam memanfaatkan desain pembelajaran tidak menutup kemungkinan tidak akan menemui kendala-kendala dalam proses pembelajaran. Kendala-kendala tersebut dipengaruhi oleh faktor manusiawi (Guru dan peserta didik), dan faktor intitusional (ruang kelas, kurangnya alat peraga dan media pembelajaran). Dalam hal ini untuk meminimalisir kendala-kendala tersebut, hendaknya guru dalam membuat desain 
pembelajaran harus disesuaikan dengan kondisi sekolah yang tidak memiliki media pembelajaran yang dibutuhkan seperti LCD, guru harus bisa menyiasati hal tersebut dengan mempersiapkan media lain yang berhubungan dengan materi pelajaran dan guru harus menetapkan aturan yang jelas dalam proses pembelajaran. Sehingga, suasana kelas tetap kondusif dan hal ini juga mengajarkan kepada siswa tentang kedisiplinan, komitmen, dan bertanggungjawab terhadap proses pembelajaran.

Selanjutnya respon siswa dapat diketahui melalui hasil wawancara dan observasi peneliti, peneliti menemukan data bahwa tedapat respon positif dan negatif siswa terhadap pemanfaatan desain pembelajaran PAI di SMA Negeri 4 Palopo. Respon positif siswa yang dimaksud adalah siswa lebih antusias dan senang karena materi yang akan disampaikan oleh gurunya sudah terdapat dibuku cetak masing-masing. Hal ini sangat memudahkan siswa dalam mengikuti proses pembelajaran. Selain itu siswa merasa puas dalam mengikuti proses pembelajaran karena guru dalam menyampaikan materi pelajaran sangat jelas dan mudah dipahami, selain itu siswa juga lebih antusias karena guru selalu mengadakan tanya jawab dan meminta siswa untuk menyimpulkan materi pelajaran disetiap akhir jam pelajaran. Jadi, Siswa harus siap dengan pertanyaan yang akan diajukan oleh guru dan secara tidak langsung membuat siswa lebih aktif terlibat dalam proses pembelajaran. Selain itu siswa lebih antusias dan senang karena materi yang akan di sampaikan oleh guru sudah terdapat dibuku cetak. Jadi, ini sangat memudahkan siswa dalam mengikuti proses pembelajaran, dan siswa merasa lebih fokus dalam mengikuti proses pembelajaran karena saya siswa sudah siap dengan al-Qur'an dan terjemahannya, jadi materi yang dipelajari dapat saya pahami dengan baik.

Keterlibatan siswa dalam proses belajar mengajar memang sangat dibutuhkan. Keaktifan siswa dapat didorong oleh peran guru. Guru harus berupaya untuk memberi kesempatan siswa untuk aktif, baik itu aktif mencari, aktif memproses dan mengelolah perolehan belajarnya. Untuk dapat meningkatkan keterlibatan siswa dalam proses belajar mengajar guru dapat melakukannya dengan cara melibatkan siswa baik itu secara individu maupun kelompok, menciptakan peluang yang mendorong siswa untuk melakukan eksperimen, memberi tugas kepada siswa untuk memperoleh informasi dari sumber luar kelas atau sekolah dan melibatkan siswa dalam dalam merangkum atau menyimpulkan materi yang telah diajarkan.

Adapun respon negatif siswa yang dimaksud adalah siswa merasa bahwa pembelajaran yang berlangsung sangat kurang maksimal karena guru hanya menjelaskan secara singkat materi yang dipelajari alasannya karena tidak adanya LCD yang akan digunakan untuk menampilkan power point jadi kebanyakan waktu digunakan untuk mengecek hafalan sholat siswa dan siswa juga merasa bosan bahkan mengantuk dalam mengikuti proses pembelajaran karena dalam guru menyampaikan materi pelajaran selalu menggunakan metode ceramah saja tanpa memberikan kesempatan untuk menanyakan materi yang kurang dipahami.

Proses pembelajaran di kelas merupakan suatu proses yang kompleks. Kegiatan harus direncanakan dengan matang dan dikemas dengan menarik 


\section{4 | Nur Amalina}

agar siswa tertarik untuk belajar. Dalam proses pembelajaran tidak memungkiri bahwa adanya respon negatif dari siswa, jadi guru sebaiknya memfasilitasi siswa untuk aktif. Guru harus mengkolaborasikan dengan materi pelajaran yang sedang dipelajari, guru juga dapat menyampaikan cerita pribadi yang berhubungan dengan materi pembelajaran untuk mengungkapkan ketertarikannya pada materi yang sedang dibahas dan menggunakan humor dikelas juga dapat mengurangi tekanan pada siswa saat belajar. Usaha guru dalam mengurangi respon negatif siswa dalam proses pembelajaran juga dengan menciptakan hubungan baik antara guru dan peserta didik, dan guru juga harus memastikan bahwa setiap siswa mendapatkan perlakuan yang sama. Usaha guru tersebut selain mengurangi respon negatif siswa terhadap kegiatan pembelajaran, juga dapat berpengaruh kepada hubungan positif antar siswa dan guru.

Hasil penelitian ini sejalan dengan penelitian yang pernah dilakukan sebelumnya. Penelitian Junita menemukan bahwa evaluasi terhadap context, bentuk desain penilaian pembelajaran PAI yang digunakan di SMA Negeri 4 Palopo berbasis kurikulum 2013 dan dirumuskan bersama di forum MGMP. Kualifikasi guru sudah sesuai dengan latar belakang pendidikan namun kompetensi pedagogik sebagaian guru masih kurang maksimal dan faktor penunjang sudah ada namun kurang memadai. Evaluasi terhadap input, dukungan sekolah dan usaha guru masih kurang maksimal. Evaluasi process, pemanfaatan desain penilaian pembelajaran PAI belum sesuai. Evaluasi product, pemanfaatan desain penilaian pembelajaran PAI menimbulkan dampak positif bagi guru maupun siswa serta respon siswa menimbulkan respon negatif. 39

\section{Kesimpulan}

Berdasarkan hasil analisis data maka dapat disimpulkan bahwa ditinjau dari aspek context, bentuk desain pembelajaran PAI yang digunakan adalah desain pembelajaran PAI berbasis kurikulum 2013 yang dirumuskan secara bersama dan individu dan bertujuan untuk melengkapi administrasi pembelajaran, sebagai alat ukur efektif tidaknya suatu proses pembelajaran ,dan membantu guru dalam memandu proses pembelajaran. Adapun kualifikasi guru sudah sesuai dengan latar belakang pendidikannya dan kompetensi sebagian guru masih kurang maksimal khususnya kompetensi pedagogik yaitu kemampuan guru dalam merancang proses pembelajaran dan faktor penunjang yaitu komputer, kertas dan printer. Ditinjau dari aspek input, dukungan sekolah masih kurang maksimal dan usaha guru masih juga kurang maksimal. Ditinjau dari aspek process, kesesuaian pemanfaatan desain pembelajaran PAI terkadang sesuai dan terkadang juga tidak sesuai. Adapun waktu pembuatan desain pembelajaran PAI dilakukan setiap awal semester walaupun terkadang perangkat pembelajaran belum selesai semuanya dan masa pemanfaatan desain pembelajaran PAI berlaku untuk

\footnotetext{
${ }^{39}$ Junita, Evaluasi Program Desain Penilaian Pembelajaran Pendidikan Agama Islam Melalui Model Context, Input, Process, Product di SMA Negeri 4 Palopo, Tesis, (Palopo: Prodi Manajemen Pendidikan Islam Institut Agama Islam Negeri Palopo, 2016), h. 118.
} 
satu semester. Ditinjau dari aspek product, dampak pemanfaatan desain pembelajaran PAI menimbulkan dampak positif dan dampak negatif dan respon siswa juga menimbulkan respon positif dan respon negatif.

Disarankan agar kompetensi guru PAI dapat terus ditingkatkan dan kemampuan sekolah dalam menyusun desain pembelajaran PAI serta meningkatkan kemampuan manajerial dan kepemimpinan kepala sekolah dalam meberdayakan forum MGMP.

\section{Daftar Pustaka}

Abdul Majid, dan Dian Andayani, "Pendidikan Agama Islam Berbasis Kompetensi:Konsep dan Imlementasi Kurikulum 2004", Bandung: Rosdakarya, 2004.

Abdul Majid, "Perncanaan Pembelajaran", Bandung: Remaja Rosda Karya, 2007.

Afnil Guza, "Standar Nasional”, Jakarta: Asa Mandiri, 2008.

Astin Lukum, "Evaluasi Program Pembelajaran IPA SMP Menggunakan Model Countenance Stake," Penelitian dan Evaluasi Pendidikan, Nomor 2 Volume $19 \quad$ Universitas Gorontalo, 2015, http://journal.uny.ac.id/index.php/jpep.

Azhar Arsyad, "Media Pembelajaran", Jakarta: Raja Grafindo Persada, 2000.

Basyiruddin Usman, "Metodologi Pembelajaran Agama Islam", Jakarta: Ciputat Pers, 2002.

Bermawi Munthe, "Desain Pembelajaran”, Yogyakarta: Insan Madani, 2012.

Barnawi \& M. Arifin, "Manajemen Sarana \& Prasarana Sekolah", Jogjakarta: Ar-Ruzz Media, 2012.

Barnawi \& M. Arifin “Kinerja Guru Profesional”, Jogjakarta: Ar-Ruzz Media, 2012.

Burhan Bungin, "Penelitian Kualitatif:Komunikasi, Ekonomi, Kebijakan Publik, dan Ilmu Sosial Lainnya", Jakarta: Kencana Prenada Media Group, 2010.

David, J. R, “Teaching Strategies for The College Classroom”, London: Westview Press, 2004.

Deby Arisma, "Evaluasi Program Pendidikan Sistem Ganda Di Sekolah Menengah Kejuruan Melalui Model CIPP (Studi Kasus Di SMK Bhinneka Karya Surakarta Jurusan Otomatif)", Tesis, Surakarta: Prodi Tehnologi Pendidikan Universitas Sebelas Maret Surakarta, 2013.

Direktorat Jenderal Peningkatan Mutu Pendidikan dan Tenaga Kependidikan dan Jenderal Pendidikan Tinggi, Prosedur Operasional Standar Penyelenggaraan KKG dan MGMP, Jakarta: Kementerian Pendidikan Nasional, 2010.

Douglas Brown, "Teaching by Principal: an Interaction Approach to Language Pedagogy", USA: Person Education, 2007.

Douglas Brown, "Principles of Language Learning and Teaching", USA: Person Education, 2007.

Fatah NC Syukur, "Teknologi Pendidikan", Semarang: Rasail Media Grup, 2008. 


\section{6 | Nur Amalina}

Fuat Iskandar, "Evaluasi Pelaksanaan Program Pendampingan Penyelenggaraan Pendidikan Kejuruan Direktorat Pembinaan SMK Melalui Model CIPP (Studi Kasus di Universitas Sebelas Maret)", Tesis, Jakarta: Prodi Ilmu Administrasi Kekhususan Administrasi dan Kebijakan Pendidikan, Universitas Indonesia, 2012.

Gusti Nono Haryono, "Studi Evaluasi Program Pendidikan Inklusif Bagi Anak Berkebutuhan Khusus Melalui Model CIPP", Tesis, Pontianak: Untan Pontianak, 2005.

Hamzah B Uno, "Perencanaan Pembelajaran”, Jakarta: Bumi Aksara, 2006.

Hilal Mahmud, "Administrasi Pendidikan, (Menuju Sekolah Efektif)", Makassar: Aksara Timur , 2015.

Iskandar, "Metodologi Penelitian Pendidikan dan Sosial (Kuantitatif dan Kualitatif)", Cet.II; Jakarta: Gaung Persada Press, 2009.

Junita, "Evaluasi Program Desain Penilaian Pembelajaran Pendidikan Agama Islam Melalui Model Context, Input, Process, Product di SMA Negeri 4 Palopo", Tesis, Palopo: Prodi Manajemen Pendidikan Islam Institut Agama Islam Negeri Palopo, 2016.

Lexy J Moleong, "Metodologi Penelitian Kualitatif", Bandung: Remaja Rosdakarya, 2005.

Muhammad Yaumi, "Prinsip- Prinsip Desain Pembelajaran”, Jakarta: Kencana, 2013

Mulyasa, "Implementasi Kurikulum 2004 Panduan Pembelajaran KBK", Bandung: Remaja Rosdakarya, 2004.

Oemar Hamalik, "Kurikulum dan Pembelajaran”, Jakarta: Bumi Aksara, 2002.

Paul Suparno, "Teori Perkembangan Kognitif Jean Pieget", Yogyakarta: Kanisius, 2001.

Pat Hollingsworth, "Active Learning:Increasing Flow In the Classroom", diterjemahkan oleh: Dwi Wulandari dengan judul: "Pembelajaran Aktif", Bandung: Rineka Cipta , 2008.

Peraturan Bersama Mentri Pendidikan Nasional tentang Pelaksanaan Jabatan Fungsional Guru Nomor 14 Tahun 2010.

Peraturan Menteri Agama Republik Indonesia Nomor 16 Tahun 2010 tentang Pengelolaan Pendidikan Agama pada Sekolah.

Permendiknas Nomor 22 tahun 2006, Tentang Standar Isi dan Kompetensi Dasar Tingkat SMA-MA-SMK-MAK, Jakarta: Sinar Grafika, 2006.

Peraturan Pemerintah Republik Indonesia Nomor 32 Tahun 2015 Pasal 1 ayat 5, Tentang Standar Nasional Pendidikan.

Pupuh F dan Sobry S, "Strategi Belajar Mengajar", Bandung: Refika Aditama, 2007.

Prawiradilaga dan Dewi Salma, "Prinsip Desain Pembelajaran", Jakarta: Kencana Prenada Media Group, 2007.

Republik Indonesia, Undang-Undang Republik Indonesia Nomor 14 Tahun 2005 Tentang Guru dan Dosen, Bab IV, Pasal 8, ayat 1.

Sugiyono, "Memahami Penelitian Kualitatif", Bandung: Alfabeta, 2012.

Sugiyono, "Metode Penelitian Pendidikan, Pendekatan Kuantitatif \& kualitatif", Bandung: Alfabeta, 2012. 
Suharsimi Arikunto, "Metodologi Penelitian: Suatu Pendekatan Praktek",; Jakarta: Rineka Cipta, 2010.

Suharsimi Arikunto \& Cepi Safruddin Abdul Jabar, “Evaluasi Program Pendidikan", Bumi Jakarta: Aksara, 2010.

Sukring, "Pendidik dan Peserta didik dalam Pendidikan Islam", Yogyakarta: Graha Ilmu, 2013.

Sorby M. Sutikno, "Belajar dan Pembelajaran”, Prospect: Bandung,2009.

St. Marwiyah, "Perencanaan Pembelajaran Pendidikan Agama Islam", Makassar: Aksara Timur, 2015.

Syamsu Sanusi, “Strategi Pembelajaran”, Makassar: Aksara Timur, 2015.

Wina Sanjaya, "Perencanaan dan Desain Sistem Pembelajaran", Jakarta: Kencana Prenada Media Group, 2010. 
148 | Nur Amalina

HALAMAN INI SENGAJA DIKOSONGKAN 